\title{
Pengaruh Moral Reasoning Auditor Terhadap Kompetensi dan Independensi Auditor Pada Kantor BPK RI Perwakilan Propinsi Sulawesi Barat
}

\author{
Anwar \\ (STIEM Bongaya) \\ email: anwar@stiem-bongaya.ac.id
}

\begin{abstract}
Abstrak
Tujuan dari penelitian ini adalah untuk mengetahui pengaruh moral reasoning auditor pemerintah terhadap kompetensi dan independensi auditor pada kantor BPK RI perwakilan Propinsi Sulawesi Barat. Dengan adanya temuan tersebut diharapkan menjadi referensi bagi pihak terkait sebagai bahan evaluasi dalam meningkatkan kompetensi dan independensi auditor pemerintah. Penelitian ini juga dapat dijadikan bahan masukan bagi pengembangan kode etik akuntan.

Populasi dalam penelitian ini adalah auditor yang bekerja pada Badan Pemeriksa Keuangan Republik Indonesia Perwakilan Provinsi Sulawesi Barat yang berjumlah 31 orang. Teknik yang digunakan dalam pengambilan sampel adalah teknik Nonprobality Sampling (Sampel jenuh).

Hasil penelitian menunjukkan bahwa variabel moral reasoning tidak berpengaruh dan tidak signifikan terhadap kompetensi, sedangkan variabel moral reasoning berpengaruh signifikan terhadap independensi.
\end{abstract}

Kata Kunci : moral reasoning auditor, kompetensi, independensi

\section{PENDAHULUAN}

\section{A. Latar Belakang}

Prinsip-prinsip pemerintahan yang baik (good governance) telah menjadi barometer dalam mengukur keberhasilan pengelolaan pemerintahan. Mardiasmo (2006) mengemukakan ada tiga aspek penting untuk mewujudkan good governance yakni pengawasan, pengendalian, dan pemeriksaan. Pemeriksaan (audit) merupakan kegiatan yang dilakukan oleh pihak yang memiliki independensi dan kompetensi profesional untuk memeriksa apakah hasil kinerja pemerintah telah sesuai dengan standar yang telah ditetapkan (Setyaningrum, 2012).

Lembaga yang diamanatkan untuk melaksanakan tugas pemeriksaan ini diantaranya adalah Badan Pemeriksa Keuangan Republik Indonesia (BPK) RI dan Inspektorat Provinsi. Badan Pemeriksa Keuangan (BPK) adalah salah satu lembaga Negara yang bertugas untuk memeriksa pengelolaan dan tanggung jawab keuangan Negara yang disebutkan juga dalam Undang-undang Dasar Republik Indonesia tahun 1945. BPK sebagai satu lembaga tinggi Negara yang bebas dan mandiri serta berperan penting dan strategis dalam menilai kinerja keuangan yang dilakukan oleh Pemerintah Pusat, Pemerintah Daerah, Badan Usaha Milik Daerah, Badan Layanan Umum dan Lembaga Negara lainnya yang mengelola keuangan Negara berdasarkan Undang-Undang tentang pemeriksaan, pengelolaan dan tanggung jawab keuangan Negara. Salah satu cara yang dapat digunakan oleh auditor untuk memelihara nilai-nilai profesionalisme sebagai suatu standar etika atau kode etik adalah dengan mengandalkan pemahaman atas moral reasoning (Gaffikin dan Lindawati, 2012).

Moral reasoning (penalaran moral) sebagai salah satu faktor yang dianggap memiliki pengaruh terhadap kualitas audit yang juga sering disebut sebagai kesadaran 
moral (moral judgment/moral thinking) merupakan sebuah proses penentuan benar atau salah yang dialami seorang individu dalam suatu situasi yang menjadi faktor penentu dalam pengambilan keputusan etis (Januarti dan Faisal, 2010).

Oleh karena itu, moral reasoning sangat penting untuk dimanfaatkan oleh auditor dalam rangka meningkatkan kualitas auditnya. Moral Reasoning menurut Cohen Pen and Sharp (1996) dalam Herawati dkk (2013), merupakan kesadaran modal (moral judgment, moral thinking), alasan moral merupakan faktor yang menentukan perilaku moral dalam pengambilan keputusan etis. Dalam hal ini alasan moral diperoleh dari proses pembelajaran dan penalaran ilmiah yang dilakukan seseorang (auditor).

Kualitas audit yang diungkapkan DeAngelo (1981) dalam Alim dkk (2007), yaitu sebagai Probabilitas dimana seorang auditor menemukan dan melaporkan tentang adanya suatu pelanggaran dalam sistem akuntansi kliennya. De Angelo (1981) mendefinisikan Kualitas audit sebagai kemampuan auditor menemukan pelanggaran pada laporan keuangan yang tidak sesuai dengan Generelly Accepted Accounting Principles (GAAP).

Pengujian moral reasoning sebagai faktor yang memengaruhi kualitas audit didasarkan pada realita yang menunjukkan bahwa kualitas audit pada sektor publik sering dianggap tertinggal dibandingkan dengan kualitas audit pada sektor swasta. Hal inilah yang memunculkan keinginan berbagai pihak termasuk peneliti untuk mengeksplor berbagai faktor yang dapat memengaruhi kualitas audit.

Selain itu, alasan penetapan moral reasoning sebagai satu-satunnya variable yang memengaruhi kualitas audit dalam penelitian ini karena adanya pertentangan hasil pada penelitian-penelitian sebelumnya mengenai pengaruh moral reasoning terhadap kualitas audit. Penelitian mengenai Moral Reasoning auditor pemerintah dan kualitas audit sudah dilakukan oleh beberapa peneliti sebelumnya, penelitian ini menduplikasi penelitian yang dilakukan oleh Januarti dan Faisal (2010) penelitiannya yang berjudul "Pengaruh Moral Reasoning dan Skeptisisme Profesional Auditor Pemerintah Terhadap Kualitas Audit Laporan Keuangan Pemerintah Daerah" (Pada BPK Pusat, BPK RI Perwakilan Kalimantan Barat dan Sulawesi Selatan). Penelitian ini menghasilkan kesimpulan bahwa moral reasoning berpengaruh negatif dengan kualitas audit, sedangkan skeptisisme profesional auditor mempunyai pengaruh positif terhadap kualitas audit.

Pembedakan penelitian ini dengan penelitian Januarti dan Faisal (2010) dan Alkam (2013) yaitu, penelitian ini hanya mengunakan dua variabel taitu Moral Reasoning dan Kualitas audit dengan indikator kompetensi dan independensi. Serta Objek yang digunakan pun berbeda Januarti dan Faisal (2010) melakukan penelitian pada BPK Pusat, BPK RI Perwakilan Kalimantan Barat dan Sulawesi Selatan dan Alkam (2013) melakukan penelitian pada BPK RI Perwakilan Provinsi Sulawesi Selatan dan Inspektorat Provinsi Sulawesi Selatan, sedangkan penulis sendiri menggunakan BPK RI Perwakilan Provinsi Sulawesi Barat sebagai Objek. Penelitian ini dianggap penting karena penelitian mengenai etika masih sangat jarang terutama di lingkungan sektor publik.

Selain itu, pengembangan mengenain topik-topik baru dalam rangka meningkatkan kinerja auditor maupun kualitas audit semakin dibutuhkan mengingat meningkatnya kompleksitas permasalahan yang sering dialami institusi sektor publik. 


\section{B. Rumusan Masalah}

Berdasarkan uraian permasalahan tersebut, maka rumusan masalah dalam penelitian ini adalah: apakah moral reasoning auditor pemerintah berpengaruh terhadap kompetensi auditor dan apakah moral reasoning auditor pemerintah berpengaruh terhadap independensi auditor pada BPK RI Sulawesi Barat?

\section{Tujuan Penelitian}

Berdasarkan masalah pokok yang telah dipaparkan sebelumnya, maka tujuan yang ingin dicapai dalam penelitian ini adalah: Untuk mengetahui pengaruh moral reasoning auditor pemerintah terhadap kompetensi auditor dan untuk mengetahui pengaruh moral reasoning auditor pemerintah terhadap independensi pada BPK RI Sulawesi Barat.

\section{TINJAUAN PUSTAKA}

\section{A. Teori Moral Reasoning}

Moral reasoning dapat didefinisikan baik itu sebagai sebuah penjelasan mengenai bagaimana individu harus bertingkah laku ataukah sebagai alasan-alasan yang muncul dalam membenarkan atau mengkritik tingkah laku. Keberadaan moral reasoning adalah untuk menunjukkan mengapa sebuah tindakan dianggap salah atau mengapa sebuah keputusan dianggap benar. Jadi, moral reasoning memberikan alasan-alasan dalam mengikuti atau melawan keyakinan moral sebagai usaha untuk menunjukkan bahwa keyakinan tersebut benar ataukah salah (Gaffikin dan Lindawati,2012 dalam Fox and DeMarco,1990).

Definisi lain moral reasoning adalah sebuah penjelasan yang tujuannya adalah untuk menjelaskan proses yang dialami seorang individu dalam mengambil sebuah keputusan etis, atau menggambarkan sebuah proses pembentukan tingkah laku berdasarkan penilaian moral individu (cognition-judgment-action process). Jadi, proses moral reasoning yang terjadi pada seorang individu juga dapat dipahami dengan menguji bagaimana seorang individu menginternalisasi standar-standar moral. (Gaffikin dan Lindawati, 2012 dalam Adams et al, 1995).

Berdasar teori dan temuan penelitian yang ada, perkembangan moral memengaruhi keinginan auditor untuk menyetujui tekanan pengaruh sosial yang tidak memadai yang dihasilkan dari dalam entitas. Oleh karenanya, auditor pada level perkembangan moral yang lebih rendah menjadi lebih rentan atas obedience pressure and conformity pressure (tekanan ketaatan dan tekanan kesesuaian) dibanding auditor pada tahap perkembangan moral yang lebih tinggi (Faisal, 2007 dalam Lord and DeZoort, 2001).

Proses penalaran moral (moral reasoning) juga membentuk bagian dari keseluruhan kesadaran moral pada sebuah sistem kepercayaan seseorang yang menghasilkan sebuah keputusan ketika seorang individu menghadapi sebuah dilema yang sulit (Gaffikin dan Lindawati, 2012, dalam Au and Wong, 2000).

\section{B. Kualitas Audit}

Kegiatan audit atas keuangan pemerintah dilakukan oleh auditor pemerintah. Auditor Pemerintah adalah auditor yang bekerja di instansi pemerintah yang tugas utamanya adalah melakukan audit atas pertanggungjawaban keuangan dari berbagai unit organisasi dalam pemerintahan. Auditing ini dilaksanakan oleh auditor pemerintahan yang bekerja di BPKP dan BPK. Disamping itu, ada auditor pemerintah yang bekerja di Direktorat Jenderal Pajak (Halim, 2008:11).

Tugas yang diemban BPK merupakan perwujudan pasal 23 ayat 5 UndangUndang Dasar 1945 yang berbunyi: "Untuk memeriksa tanggung jawab tentang keuangan negara diadakan suatu Badan Pemeriksa Keuangan (BPK) yang 
pengaturannya ditetapkan dengan Undang-Undang. Hasil pemeriksaan itu diberitahukan kepada Dewan Perwakilan Rakyat (DPR)ee.

Kualitas audit ditentukan oleh dua hal yaitu kompetensi dan independensi (Alim, dkk, 2007 dalam Christiawan, 2002). De Angelo (1981) mendefinisikan kualitas audit sebagai probabilitas bahwa auditor akan menemukan dan melaporkan pelanggaran pada sistem akuntansi klien. Kompetensi dan independensi yang dimiliki auditor dalam penerapannya adalah untuk menjaga kualitas audit dan terkait dengan etika (Sari, 2011 dalam Kharismatuti, 2012). Berikut adalah uraian mengenai beberapa dimensi kualitas audit yaitu kompetensi dan independensi.

1) Kompetensi Lee and Stone (1995) dalam Indah (2010) mendefinisikan kompetensi sebagai sebuah keahlian yang secara eksplisit digunakan oleh auditor untuk melakukan tugas auditnya secara objektif. Irawati (2011) menyimpulkan bahwa kompetensi seorang auditor diperoleh dari pengetahuan dan pengalaman. Pengetahuan dan pengalaman dapat bersifat umum dengan standar tinggi yang diikuti melalui pendidikan khusus, sertifikasi, serta pengalaman kerja. Kompetensi yang diperoleh ini harus selalu dipertahankan dan dikembangkan dengan terus-menerus mengikuti penerbitan nasional dan internasional yang relevan dengan akuntansi, auditing, dan keterampilan-keterampilan teknis lainnya (Murwanto dkk, 2006 ; 54).

2) Independensi Definisi independensi dalam The CPA Handbook menurut E.B. Wilcox (Alim dkk, 2007) adalah merupakan suatu standar auditing yang penting karena opini akuntan independen bertujuan untuk menambah kredibilitas laporan keuangan yang disajikan oleh manajemen. Jika akuntan tersebut tidak independen terhadap kliennya, maka opininya tidak akan diberikan tambahan apapun. Mulyadi dan Puradiredja (1998) dalam Wati (2010) juga mendefinisikan independensi sebagai kejujuran dalam diri auditor dalam mempertimbangkan fakta dan adanya pertimbangan yang objektif serta tidak memihak dalam diri auditor dalam merumuskan maupun menyatakan pendapat. Supriyono (1988) dalam Alim dkk (2007) telah melakukan penelitian mengenai independensi auditor di Indonesia. Penelitian ini mempelajari faktor- faktor yang mempengaruhi independensi auditor yaitu (1) ikatan keputusan keuangan dan hubungan usaha dengan klien; (2) persaingan antara KAP; (3) pemberian jasa lain selain jasa audit; (4) lama penugasan audit; (5) besar kantor akuntan; dan (6) besarnya audit fee.

\section{METODE PENELITIAN}

\section{A. Lokasi Penelitian.}

Penelitian ini dilakukan pada BPK-RI perwakilan Propinsi Sulawesi Barat yang bertempat di Jl. H. Abdul Malik Pattana Endeng, Kec. Simboro, Mamuju.

\section{B. Defenisi Operasional dan Pengukuran Variabel}

Dalam penelitian ini terdapat dua macam variabel, yaitu variabel independen dan variabel dependen.

1. Variabel bebas (independent variable), yang terdiri dari: Penalaran moral (moral reasoning) adalah proses yang dialami seorang individu dalam menentukan baik atau buruk, benar atau salah yang memengaruhinya dalam mengambil sebuah keputusan. Penelitian ini menggunakan instrument dari Multidimensional Ethics Scale (MES).

2. Variabel terikat (dependent variable), yaitu:

a. Kompetensi (Y1) Kompetensi adalah keahlian yang dimiliki oleh seorang 
auditor yang didapatkan dari pengetahuan dan pengalaman mereka. Dalam penelitian ini kompetensi diukur dengan menggunakan dimensidimensi kompetensi yang digunakan oleh Putra (2012) yaitu mutu personal, pengetahuan umum dan keahlian khusus.

b. Independensi (Y2) Independensi adalah sebuah keadaan dimana auditor tidak dipengaruhi oleh kepentingan siapapun, sehingga auditor dapat bersikap objektif dalam menjalankan tugasnya. Dalam penelitian ini independensi diukur dengan menggunakan dimensi-dimensi yang digunakan Putra (2012) yaitu: hubungan dengan klien, independensi pelaksanaan pekerjaan, dan independensi laporan.

\section{Metode Analisis Data}

Metode analisis data yang digunakan adalah:

\section{Analisis Deskriptif}

Analisis deskriptif adalah analisis yang menjelaskan atau memaparkan data hasil pengamatan tanpa melakukan pengujian statistik. Analisis ini bertujuan untuk menggambarkan karakteristik dari sebuah sampel ataupun populasi yang teramati dan dapat digambarkan lewat tabel dan gambar.

2. Analisis Inferensial

Analisis Inferensial yang digunakan untuk menjawab masalah dan sekaligus menguji hipotesis. Analisis inferensial dilakukan dengan menggunakan alat statistik parametris sesuai dengan permasalahan, tujuan, kerangka konsep dan hipotesis dalam penelitian ini, selanjutnya dikembangkan model analisis berikut ini:

$$
\begin{aligned}
& \mathrm{Y} 1=\beta_{0}+\beta_{1} \mathrm{X}_{1}+\mathrm{e} \ldots \ldots \\
& \mathrm{Y} 2=\beta_{0}+\beta_{1} \mathrm{X}_{1}+\mathrm{e} \ldots .
\end{aligned}
$$

Keterangan :

$\mathrm{Y} 1=$ Kompetensi

Y2 = Independesi

$\beta_{0}=$ Konstanta

$\beta_{1} \quad=$ Koefisien Regresi

$\mathrm{X} 1=$ Moral Reasoning

$\mathrm{E} \quad=\operatorname{Error}($ Kesalahan Residual $)$

\section{HASIL PENELITIAN}

\section{A. Hasil Pengujian Hipotesis}

Hasil uji statistik t untuk variabel moral reasoning terhadap kompetensi dapat dilihat dalam tabel, sebagai berikut:

\section{Tabel 1}

\section{Hasil Uji Statistik t Variabel Dependen Kompetensi}

\begin{tabular}{|c|c|c|c|c|c|}
\hline \multirow[t]{2}{*}{ Model } & \multicolumn{2}{|c|}{$\begin{array}{l}\text { Unstandardized } \\
\text { Coefficients }\end{array}$} & $\begin{array}{l}\text { Standardized } \\
\text { Coefficients }\end{array}$ & \multirow[t]{2}{*}{$\mathrm{t}$} & \multirow[t]{2}{*}{ Sig. } \\
\hline & B & Std. Error & Beta & & \\
\hline (Constant) & 46.223 & 8.108 & & 5.701 & .000 \\
\hline MORAL REASONING & 010 & .272 & .007 & .036 & 971 \\
\hline
\end{tabular}

\section{Coefficients}

a. Dependent Variable: KOMPETENSI

Sumber: Output SPSS 

berikut:

Berdasarkan tabel 1, maka diperoleh persamaan (model) regresi yaitu sebagai

$$
\begin{gathered}
Y_{1}=\alpha+\beta \mathrm{X}+\mathrm{e} \\
Y_{1}=46,223+0,010 \mathrm{X}+\mathrm{e} \ldots \ldots(\text { persamaan } 1)
\end{gathered}
$$

Persamaan regresi linear persamaan 1 di atas dapat dijelaskan secara rinci sebagai berikut:

1. Kompetensi memiliki nilai $\mathrm{t}$ sebesar 0,036, nilai koefisien $\mathrm{B}$ sebesar0,010 dan tingkat signifikan sebesar 0,971. Hal ini menandakan bahwa koefisien variabel (X) moral reasoning auditor pemerintah tidak memiliki pengaruh terhadap kompetensi auditor (Y1) dengan tingkat signifikan 0,971. Artinya moral reasoning auditor pemerintah tidak berpengaruh positif dan tidak signifikan terhadap kompetensi auditor karena diatas 0,05 .

2. Konstanta sebesar 46,223 berarti bahwa seorang auditor tetap memiliki kompetensi sebesar konstanta meskipun variabel independennya bebas (nol).

Berdasarkan hasil penelitian Uji t pada tabel diatas juga dapat dilihat yaitu pada nilai $\mathrm{t}$ dengan nilai $\mathrm{df}=\mathrm{n}-\mathrm{k}-1=31-1-1=29$ maka $\mathrm{t}_{\text {tabel }}$ diperoleh pada lampiran yaitu 2,045. Pada tabel 4.16 nilai kompetensi pada kolom t sebesar 0,036, nilai $t_{\text {hitung }}$ lebih kecil dari $\mathrm{t}_{\text {tabel }}$ yaitu $0,036<2,045$ maka $\mathrm{H} 1$ ditolak berarti secara parsial variabel moral reasoning auditor pemerintah tidak berpengaruh terhadap kompetensi auditor.

Dari hasil perhitungan ini, dapat pula diperoleh bahwa antara moral reasoning auditor pemerintah terhadap kompetensi auditor tidak terdapat pengaruh positif dan tidak signifikan pada tingkat kepercayaan $(\alpha=0,05)$ dengan nilai signifikan diperoleh sebesar 0,971 lebih besar dari 0,05.

Selanjutnya, hasil uji statistik $\mathrm{t}$ untuk variabel moral reasoning terhadap independensi dapat dilihat dalam tabel, sebagai berikut:

Tabel 2

Hasil Uji Statistk t Variabel Dependen Independensi

\begin{tabular}{|c|c|c|c|c|c|}
\hline \multirow[t]{2}{*}{ Model } & \multicolumn{2}{|c|}{$\begin{array}{l}\text { Unstandardized } \\
\text { Coefficients }\end{array}$} & \multirow{2}{*}{$\begin{array}{c}\begin{array}{c}\text { Standardized } \\
\text { Coefficients }\end{array} \\
\text { Beta } \\
\end{array}$} & \multirow[t]{2}{*}{$\mathrm{T}$} & \multirow[t]{2}{*}{ Sig. } \\
\hline & B & Std. Error & & & \\
\hline (Constant) & 10.370 & 4.236 & & 2.448 & .021 \\
\hline $\begin{array}{l}\text { MORAL } \\
\text { REASONING }\end{array}$ & .502 & .142 & .549 & 3.536 & .001 \\
\hline
\end{tabular}

Coefficients $^{\mathrm{a}}$

a. Dependent Variable: INDEPENDENSI

Sumber: Output SPSS

Berdasarkan tabel 2, maka diperoleh persamaan (model) regresi yaitu sebagai berikut:

$$
\begin{gathered}
Y_{2}=\alpha+\beta \mathrm{X}+\mathrm{e} \\
Y_{2}=10,370+0,502 \mathrm{X}+\mathrm{e} \ldots \ldots(\text { persamaan } 2)
\end{gathered}
$$

Persamaan regresi linear persamaan di atas dapat dijelaskan secara rinci sebagai berikut:

1. Independensi memiliki nilai t sebesar 3,536, nilai koefisien $\mathrm{B}$ sebesar 0,502 dan tingkat signifikan sebesar 0,001. Hal ini menandakan bahwa koefisien variabel (X) moral reasoning auditor pemerintah memiliki pengaruh positif (searah) terhadap independensi auditor (Y2) dengan tingkat signifikan 0,001. Artinya moral reasoning auditor pemerintah berpengaruh positif dan signifikan terhadap independensi auditor karena dibawah 0,05 . 
2. Konstanta sebesar 10,370 berarti bahwa seorang auditor tetap memiliki independensi sebesar konstanta meskipun variabel independennya bebas (nol)

Berdasarkan hasil penelitian Uji t dapat dilihat pada tabel diatas yaitu pada nilai $\mathrm{t}$ dengan nilai $\mathrm{df}=\mathrm{n}-\mathrm{k}-1=31-1-1=29$ maka $\mathrm{t}_{\text {tabel }}$ diperoleh pada lampiran yaitu 2,045. Pada tabel 4.17 nilai independensi pada kolom t sebesar 3,536, nilai $t_{\text {hitung }}$ lebih besar dari $t_{\text {tabel }}$ yaitu 3,536 > 2,045 maka H2 diterima berarti secara parsial variabel moral reasoning auditor pemerintah berpengaruh terhadap independensi auditor.

Dari hasil perhitungan ini, dapat pula diperoleh bahwa antara moral reasoning auditor pemerintah terhadap independensi auditor terdapat pengaruh dan signifikan pada tingkat kepercayaan $(\alpha=0,05)$ dengan nilai signifikan diperoleh sebesar 0,001 lebih kecil dari 0,05 .

Penentuan hasil perhitungan regresi ini dapat disimpulkan bahwa $t_{\text {hitung }}>t_{\text {tabel }}$, maka H2 diterima. Terdapat pengaruh dan signifikan moral reasoning auditor pemerintah terhadap independensi auditor. Artinya semakin bagus tingkat moral reasoning auditor pemerintah, maka semakin tinggi independensi auditor.

\section{B. Pembahasan}

\section{Pengaruh moral reasoning terhadap kompetensi}

Berdasarkan analisis data dan hasil pengujian hipotesis, diperoleh hasil regresi sederhana dari penelitian ini bahwa moral reasoning tidak berpengaruh terhadap kompetensi. Hal ini berarti bahwa auditor pada umumnya memiliki penalaran moral yang baik tentu sadar mengenai tindakan-tindakan yang seharusnya ia lakukan dalam kapasitasnya sebagai seorang auditor pemerintah. Tindakan-tindakan tersebut tentu meliputi penambahan pengetahuan dan pengalaman dalamrangka meningkatkan kompetensi sebagai bentuk profesionalisme atas tanggung jawab yang diberikan. Akan tetapi pengetahuan dan pengalaman yang dimiliki auditor tidak memberikan kontribusi untuk meningkatkan perilaku moral auditor dalam mengambil keputusan, yang berarti moral reasoning tidak berpengaruh terhadap kompetensi auditor.

Hasil penelitian ini tidak sesuai dengan teori dan hasil penelitian sebelumnya, hasil penelitian sebelumnya yaitu Rahayu Alkam (2013), diketahui bahwa moral reasoning auditor pemerintah berpengaruh positif dan signifikan terhadap kualitas. Hal ini sesuai dengan teori perkembangan moral yang menganggap bahwa perkembangan moral yang menjadi besar dari moral reasoning berhubungan secara langsung dengan perilaku seseorang. Hubungan ini dibuktikan dengan diperolehnya hasil berupa penuh positif moral reasoning terhadap kualitas audit dilihat dari sisi kompetensi. Pengaruh ini menunjukkan bahwa kompetensi seseorang dapat ditingkatkan dengan mengembangkan moral reasoning.

2. Pengaruh moral reasoning terhadap independensi

Moral Reasoning secara parsial berpengaruh positif dan signifikan terhadap independensi auditor. Hal ini berarti bahwa independensi pada diri auditor memang memegang peranan yang penting, mengingat audit bukan hanya proses untuk menemukan salah saji material tetapi juga bagaimana melaporkan kesalahan tersebut. Kemampuan untuk melaporkan adanya salah saji material sangat bergantung pada tinggi rendahnya independensi auditor. Auditor yang melaksanakan tugasnya secara jujur, tidak memihak kepada kepentingan siapapun, dan melaporkan temuannya berdasarkan bukti-bukti yang ada tentu memberikan 
kualitas audit yang berbeda dengan auditor yang masih memihak kepada kepentingan-kepentingan pihak tertentu.

Temuan yang di peroleh di dalam tahapan pengolahan data tidak konsisten dengan hasil penelitian yang dilakukan oleh Januarti dan Faisal (2010) yang menemukan bahwa moral reasoning justru berpengaruh negatif terhadap kualitas audit. Hasil penelitian menunjukkan bahwa meskipun responden mempunyai moral reasoning yang rendah tetapi kualitas auditnya tetap baik. Hal ini diperlihatkan dengan arah hubungan yang negatif.

\section{KESIMPULAN}

Berdasarkan hasil penelitian dan pengujian yang telah dilakukan terhadap permasalahan dengan menggunakan model regresi sederhana, maka dapat diambil kesimpulan sebagai berikut:

1. Variabel moral reasoning $(\mathrm{X})$ tidak berpengaruh positif dan tidak signifikan terhadap kompetensi $\left(\mathrm{Y}_{1}\right)$. Hal ini menunjukkan bahwa semakin tinggi kompetensi seseorang tidak akan mempengaruhi dalam mengambil sebuah keputusan.

2. Variabel moral reasoning (X) berpengaruh positif dan signifikan terhadap independensi $\left(\mathrm{Y}_{2}\right)$. Hal ini menunjukkan bahwa independensi seseorang dapat ditingkatkan dengan mengembangkan moral reasoning.

\section{SARAN}

Penelitian ini di masa mendatang diharapkan dapat menyajikan hasil penelitian yang lebih berkualitas lagi dengan adanya beberapa masukan mengenai beberapa hal diantaranya:

1. Peneliti dimasa mendatang disarankan untuk memperbanyak jumlah sampel responden yang di ikut sertakan dalam tahapan pengolahan data dan mencari variabel lain yang mempengaruhi Kompetensi dan independensi auditor untuk meningkatkan akurasi hasil penelitian yang akan diperoleh dimasa mendatang.

2. Auditor disarankan untuk terus berkomitmen pada prinsip moral reasoning didalam melakukan audit, walaupun didalam penelitian ini ada yang tidak berkontribusi signifikan dalam meningkatkan kompetensi dan independensi auditor akan tetapi moral reasoning sangat penting untuk menjaga komitmen auditor untuk melaksanakan proses audit secara jujur dan optimal.

\section{DAFTAR PUSTAKA}

Agoes, Sukrisno, 2012. Auditing: Petunjuk Praktis Pemeriksaan Akuntan oleh Akuntan Publik, Edisi 4 Buku 1, Salemba Empat, Jakarta

Alim dkk, 2007. Pengaruh Kompetensi Dan Independensi Terhadap Kualitas Audit Dengan Etika Auditor Sebagai Variabel Moderasi. Simposium Nasional Akuntansi X, Makassar, 26 - 28 Juli, 2007.

Alkam, Rahayu, 2013. Pengaruh Moral Reasoning Auditor Pemerintahan Terhadap Kualitas Audit. Skripsi, Makassar: Fakultas Akuntansi Universitas Hasanuddin.

Arens, dkk, 2013. Jasa Audit dan Assurance: Pendekatan Terpadu (Adaptasi Indonesia), Buku 1, Salemba Empat, Jakarta

Ayuningtyas, H.Y., 2012. Pengaruh Pengalaman Kerja, Independensi, Obyek;tifitas, Integritas Dan Kompetensi Terhadap Kualitas Hasil Audit. Skripsi, Semarang: Fakultas Ekonomika dan Bisnis Universitas Diponegoro.

Badan Pemeriksa Keuangan, 2009. Program Reformasi Birokrasi BPK RI, Jakarta. Badan Pemeriksa Keuangan RI Perwakilan Provinsi Sulawesi Barat, tanpa tahun. Tentang BPK Perwakilan, melalui http:// www.mamuju.bpk.go.id (tanggal akses 
28 Oktober 2014). Blay, et al, 2012. Can Moral Reasoning Reduce Auditor Misreporting? An Experimental Examination of Investor Salience and an Auditor Sign-off Requirement, (Online), melalui http://ssrn.com/abstract=2061730 (tanggal akses 14 April 2014).

DeAngelo, L. E., 1981. Auditor Size and Audit Quality, Jurnal of Accounting and Economics, (Online) Vol 3:183-199, melalui http:// econpapers.repec.org/ article/ eeejaecon/ default3.htm (tanggal akses 27 April 2014)

Dellaportas, S., 2005. Ethics, Governance, and Accountability a Profesional Perpective (ed.1). Australia: John Wiley.

Djamil, N., 2011. Faktor-Faktor yang Memengaruhi Kualitas Audit pada Sektor Publik dan Beberapa Karakteristik untuk Meningkatkannya, (Online), melalui http:// www.freewebs.com/ nasrullah_djamil/ kualitasaudit.doc (tanggal akses 30 Maret 2014).

Faisal, 2007. Investigasi Tekanan Pengaruh Sosial dalam Menjelaskan Hubungan Komitmen dan Moral Reasoning terhadap Keputusan Auditor. Simposium Nasional Akuntansi X, Makassar, 17 November 2012.

Gaffikin, M., \& Lindawati, A. S. L. (2012). The moral reasoning of public accountants in the development of a code of ethics: the case of Indonesia. Australasian Accounting Business and Finance Journal, (Online), 6(1), 3-28, melalui http:// ro.uow.edu.au/ aabfj/ vol6/ iss1/ 10 (tanggal akses : 29 Maret 2014).

Ghozali, Imam, 2009. Aplikasi Analisis Multivariate dengan Program SPSS, Universitas Diponegoro, Semarang. Halim, Abdul, 2008. Auditing Dasar-Dasar Audit Laporan Keuangan, Edisi 4 Jilid 1, UPP STIM YKPN, Yogyakarta.

Hasan, M. Iqbal, 2010. Pokok-Pokok Materi Statistik 2 (Statistik Inferensif), Edisi Kedua, Bumi Aksara, Jakarta.

Herawati, dkk, 2013. Pengaruh Moral Reasoning Dan Skeptisisme Professional Auditor Pemerintah Terhadap Kualitas Audit Laporan Keuangan Pemerintah Daerah Di Kota Padang. Ejurnal Bunghatta, (online), Vol.3, No.1, melalui <http:// ejurnal.bunghatta.ac.id/index.php?journal=JFEK\&page=issue\&op=view\&path\% 5B\%5D=144> (tanggal akses : 4 April 2014).

Ikatan Akuntan Indonesia, 2011. Standar Profesional Akuntan Publik, Salemba Empat, Jakarta.

Indah, S.N., 2010. Pengaruh Kompetensi dan Independensi Auditor terhadap Kualitas Audit. Skripsi, Semarang: Fakultas Ekonomi dan Bisnis Universitas Diponegoro.

Januarti, I. dan Faisal, 2010. Pengaruh Moral Reasoning dan Skeptisisme Profesional Auditor Pemerintah terhadap Kualitas Audit Laporan Keuangan Pemerintah Daerah. Simposium Nasional Akuntansi XIII. Purwokerto.

Kasidi, 2007. Faktor-Faktor yang Memengaruhi Independensi Auditor; Persepsi Manajer Keuangan Perusahaan Manufaktur di Jawa Tengah. Tesis diterbitkan. Semarang: Program Pascasarjana Universitas Diponegoro.

Kharismatuti, N., 2012. Pengaruh Komitmen dan Independensi terhadap Kualitas Audit dengan Etika Auditor sebagai Variabel Moderasi. Skripsi. Semarang: Fakultas Ekonomi dan Bisnis Universitas Diponegoro. (Online), melalui http:// www.eprints.undip.ac.id/ 35828/ 1/KHARISMATUTI.pdf (tanggal akses : 16 April 2014).

Mardiasmo, 2009. Akuntansi Sektor Publik. Edisi 2. Yogyakarta: Penerbit Andi. 2006. Perwujudan Transparansi dan Akuntabilitas Publik Melalui Akuntansi Sektor Publik: Suatu Sarana Good Governance. Jurnal Akuntansi Pemerintah, (Online) Vol.2 No.1 hal 1-17, melalui http:// www.scribd.com/ doc/ 
55004659/ JURNAL-AKUNTANSI-PEMERINTA (tanggal akses : 2 April 2014). Mulyadi, 2013. Auditing, Edisi 6 Buku 1, Salemba Empat, Jakarta

Murwanto, R. dkk. (2006). Audit Sektor Publik Suatu Pengantar bagi Pembangunan Akuntabilitas Instansi Pemerintah. Jakarta: Departemen Keuangan RI.

Pant et al, 2000. The Effect of Perceived Fairness and Moral Development in an Agency Context, (Online), melalui http:// papers.ssrn.com/ sol3/ papers.cfm?abstract_id=922188 (tanggal akses : 17 April 2014).

Peraturan Pemerintah Nomor 60 Tahun 2008 tentang Sistem Pengendalian Intern Pemerintah (SPIP).

Pradita, R.D., 2010. Hubungan antara Kualitas Auditor dan Human Capital di Badan Pemeriksa Keuangan (BPK) dan Badan Pengawasan Keuangan dan Pembangunan (BPKP). Skripsi, Semarang: Fakultas Ekonomi dan Bisnis Universitas Diponegoro.

Praditaningrum, A.S., dan Januarti, I. 2011. Analisis Faktor-Faktor yang Berpengaruh terhadap Audit Judgement, (Online), melalui http://sna.akuntansi.unikal.ac.id/makalah/062-ASPSIA-06.pdf (tanggal akses : 12 Desember 2012).

Putra, N.A., 2012. Pengaruh Kompetensi, Tekanan Waktu, Pengalaman Kerja, Etika dan Independensi Auditor terhadap Kualitas Audit. Skripsi, Yogyakarta: Fakultas Ekonomi Universitas Negeri Yogyakarta.

Raharjo, N.P., 2012. Dampak Komitmen dan Moral Reasoning terhadap Respon Auditor dalam Pengaruh Tekanan Sosial (Studi Eksperimental Semu terhadap Auditor di Kantor Akuntan Publik Asing). Skripsi, Semarang: Fakultas Ekonomi dan Bisnis Universitas Diponegoro.

Rai, I Gusti Agung, 2008. Audit Kerja pada Sektor Publik: Konsep, Praktik, Studi Kasus, Jilid 1, Salemba Empat, Jakarta. Setyaningrum, D., 2012. Analisis Faktor-Faktor yang Memengaruhi Kualitas Audit BPK-RI, (Online), melalui http:// sna.akuntansi.unikal.ac.id/ (tanggal akses : 13 April 2014). 